\title{
GIGANTO-ACROMEGALY WITH HYPOGONADOTROPHIC HYPOGONADISM
}

\author{
MIRZA AZIZUL HOQUE ${ }^{1}$, MD. BAKHTIAR AZAM ${ }^{2}$, MD. GOLAM KIBRIA KHAN ${ }^{3}$, MD. AZHARUL HOQUE ${ }^{4}$ \\ QUAZIDEEN MOHAMMAD ${ }^{5}$
}

\section{Introduction:}

Gigantism came from Greek word 'Giant'. Pathologically, this condition results from the actions of excessive growth hormone $(\mathrm{GH})$ secretion from the pituitary gland during childhood and adolescent before the closure of epiphyseal growth plates. When the height of an individual is several standard deviations above the mean value for the same age, sex, and ethnicity, the condition is known as gigantism. Pituitary gigantism is extremely rare. If hypersecretion of growth hormone occurs after closure of epiphyseal growth plates the resulting condition is acromegaly. Most patients with gigantism also have features of acromegaly.

\section{The Case Report:}

A 17 years old unmarried Hindu male from Pirojpur with unusually tall stature was admitted into medicine unit Orange of Dhaka Medical College Hospital on 14th May, 2008. He presented with irregular throbbing frontal headache, excessive sweating and inability to rise from squatting position for 7, 5 and 3 years respectively. He was non-diabetic and normotensive. He had no history of visual disturbance, anorexia, vomiting, weight change, heat or cold intolerance and palpitation. He had no features of osteoporosis and thromboembolic events. None of his close relatives are unusually tall.

On examination, the patient was 82 inches tall with enlarged hands, feet, nose and lips but tongue, palate, thyroid and lower jaw were normal and there was no other organomegaly. His weight was $73 \mathrm{~kg}$. Axillary hairs, beard and mustache of the patient were infantile but pubic hair was present and normal. His phallus, testes and breast examination were found to be normal.

Arm span of the patient was 85 inches and standing (linear) height was 82 inches. His lower and upper segments were 45 inches and 37 inches respectively. No skeletal deformity or hyper mobility in any joint was found. The muscle power of the extensor group of hip was $4 / 5$ but that of all other groups of the body were normal. All peripheral pulses were normal and cardiovascular system examination revealed no abnormality. Examination of other systems also revealed no abnormality.

Heamoglobin percentage of the patient was $50 \%$ but total and differential counts of his white blood cells were within the normal limit. His random blood sugar, blood urea, and serum creatinine were within normal range and routine urine examination, chest X-ray, ECG and echocardiography revealed no abnormality.

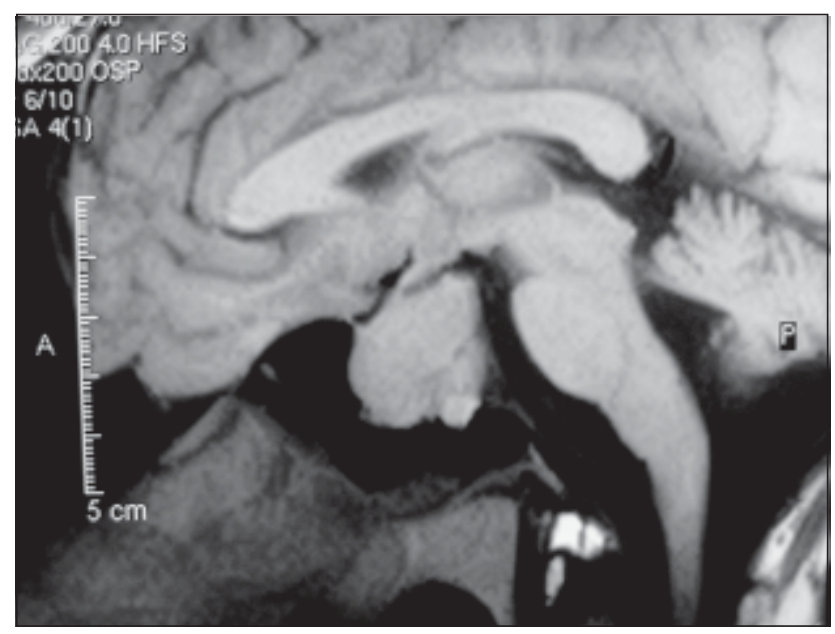

Fig.-1: MRI showing large pituitary tumour.

Hormonal assays showed Basal GH: $>40 \mathrm{ng} / \mathrm{ml}$ (normal 0.06-5 ng/ml), Morning Serum cortisol : 2.29 $\mu \mathrm{g} / \mathrm{dl}$ (normal $4.45-22.68 \mu \mathrm{g} / \mathrm{dl}$ ), Serum testosterone : $4.90 \mathrm{nmol} / \mathrm{L}$ (normal $4.56-28.20 \mathrm{nmol} / \mathrm{L}$ ), Serum FSH : $3.06 \mathrm{mIU} / \mathrm{ml}$ (normal 1.0-8.0 mIU/ml), Serum LH :

1. Associate Professor of Endocrinology, Dhaka Medical College, Dhaka

2. Registrar (Medicine Unit- Orange), Dhaka Medical College Hospital, Dhaka

3. Associate Professor of Medicine, Dhaka Medical College, Dhaka

4. Associate Professor of Neurology, Dhaka Medical College, Dhaka

5. Professor \& Head, Department of Neurology, Dhaka Medical College. Principal, Dhaka Medical College.

Correspondence : Dr. Mirza Azizul Hoque, Associate Professor of Endocrinology, Dhaka Medical College, Dhaka 


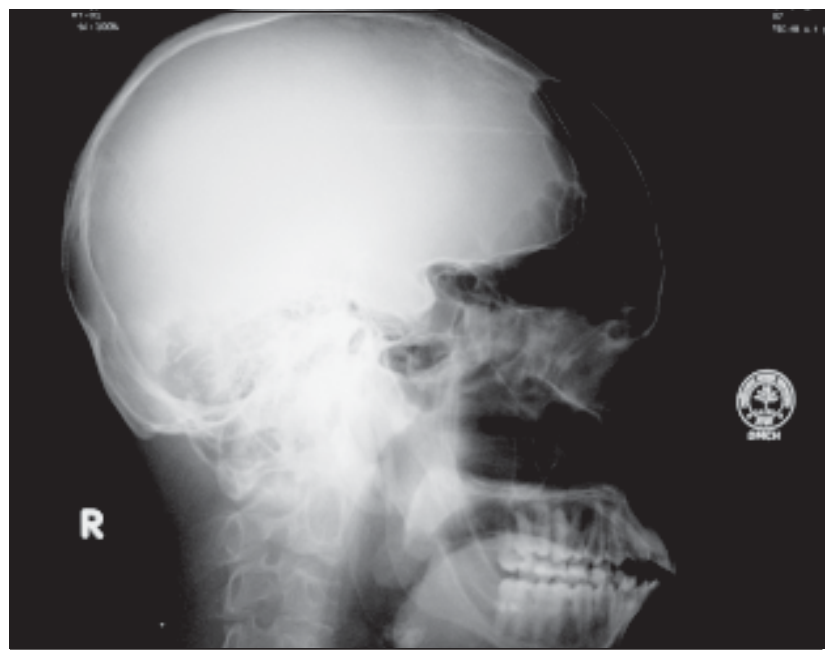

Fig.-2: X-ray skull showing enlarged air sinuses.

$1.13 \mathrm{mIU} / \mathrm{ml}$ (normal 2.0-12.0 mIU/ml), Serum TSH : $1.27 \mu \mathrm{IU} / \mathrm{ml}$ (normal 0.6-4.5 $\mu \mathrm{IU} / \mathrm{ml}$ ), Serum FT4: $1.71 \mathrm{ng} / \mathrm{dl}$ (normal 0.9-1.9 ng/dl), Serum FT3: 2.30 $\mathrm{pg} / \mathrm{ml}$ (normal 1.21-4.18 pg/ml), Serum calcium : 8.9 $\mathrm{mg} / \mathrm{dl}$ (normal 8.5-10.5 mg/dl) and Serum Prolactin : $23 \mathrm{ng} / \mathrm{ml}$ (normal 0.94-20.94 ng/ml).

Serum electrolytes estimation of the patient revealed $\mathrm{Na}^{+}-132 \mathrm{mmol} / \mathrm{L}, \mathrm{Cl}^{-}-96 \mathrm{mmol} / \mathrm{L}, \mathrm{K}^{+}-4.33 \mathrm{mmol} /$ $\mathrm{L}, \mathrm{CO}_{2}-22 \mathrm{mmol} / \mathrm{L}$.

Perimetry revealed upper arcuate scotoma of both the eyes suggestive of anterior ischemic optic atrophy or glaucoma.

MRI of brain specially the pituitary and hypophyseal region of the patient showed a large pituitary tumor $\left(2.5 \mathrm{~cm}{ }^{\prime} 2.5 \mathrm{~cm}^{\prime} 3.1 \mathrm{~cm}\right)$ with suprasellar and sphenoidal extension with no definite compression or

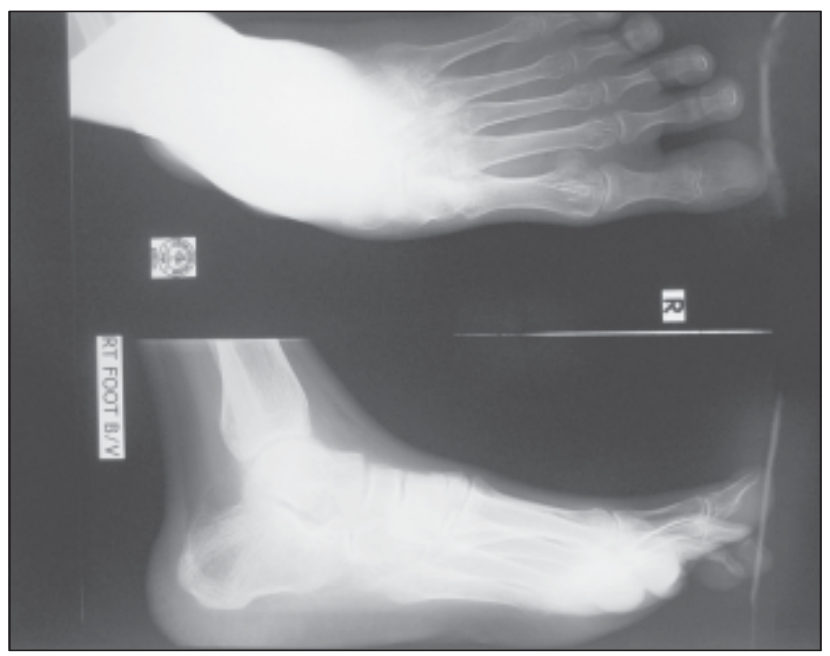

Fig.-3: X-ray foot showing increased heal pad thickness. vascular encasement (Fig.-1). X-rays of the skull and cone down view of the pituitary showed deepening and widening of the sella tursica, enlargement of paranasal air sinuses and mastoid air cells and mild protrusion of the lower jaw suggestive of prognathism (Fig.-2).

$\mathrm{X}$-ray foot showed increased heel-pad thickness of 30 $\mathrm{mm}$ (Fig.-3). X-ray of long bone showed thick and nonfused epiphyseal plates and prominent trabecullar pattern suggestive of mild osteoporosis. Radiological metacarpal index was 7 (normal - <10). Sesamoid index was also normal 36 (normal up to 40).

\section{Discussion:}

Gigantism and acromegaly may be considered as the two disorders along a range of effects of excess GH secretion and the age at which such excess activities starts will determine which one will be manifested. ${ }^{1}$ This postulation is supported by the fact that $10 \%$ of the acromegalics exhibit features of gigantism and majority of the giants eventually develop some manifestations of acromegaly. 1,2,3 Though acromegaly is not very uncommon, true gigantism is extremely rare. In a review report since 1927 only 22 cases of pituitary gigantism was found..$^{4,5}$ In another series the incidence of acromegaly is calculated to be three to four cases per million per year ${ }^{1,6}$, whereas reported cases of gigantism are only about $100 .{ }^{1,2}$ Although these evidences are probably an underestimate of the true number ${ }^{1}$, even then, it indicates the extreme rarity of gigantism.

The cardinal clinical feature of giagantism is growth acceleration. Other clinical features of gigantism are not well documented due to the rarity of affected cases but myriads of clinical features of acromegaly are well documented. ${ }^{1}$ Anthropometrical measurement our patient are compatible with Marfan's syndrome but our patient obviously was not a case of that syndrome. We did not find any reported case of gigantism that showed this type of anthropometrical measurements. A probable cause of this eunuchoid body proportion may be the hypogonadotrophic hypogonadism (discussed below) found in our patient.

A review of clinical case reports of gigantism reveals several common features among such patients. All have been noted to have coarse facial features and disproportionately large hands and feet with thick fingers and toes. ${ }^{1}$ These features were present in our patient. Frontal bossing and a prominent jaw have frequently been present ${ }^{1}$ but our patient did not have 
prominent jaw on physical examination but radiologically mild prominence was present. No frontal bossing was there. Organomegaly and deteriorating glucose tolerance were also documented in one patient observed over several years before treatment but in this case these were absent. ${ }^{1,7}$

The weight of the patient was $73 \mathrm{~kg}$ and thus BMI was 16.83 indicating that he was an underweight subject but mild to moderate obesity was common among the reported cases ${ }^{1}$. This is likely to be the result of undernourishment because of his poor economic status.

The median age of diagnosis in gigantism is 12 years but that of our patient was 17 years. The median age of initial symptoms was 8 years but that of our patient was 10 years. ${ }^{4}$

Most of the patients of gigantism usually have associated hypogonadism and features of it come early ${ }^{8}$, but in our case low levels of gonadotrophins as well as testosterone were present. Therefore, eunuchoid body habitus may be contributed by hypogonadotrophic hypogonadism. However, beard, moustache and axillary hair was absent in this case which either may be the normal finding at the age of 17 or may be due to adrenal androgen deficiency or due to hypogonadotrophic hypogonadism as discussed below.

Fatigability and inability to rise from squatting position with $4 / 5$ muscle power of extensor group of hip was present in our patient. Although, fatigability was found in gigantism ${ }^{1,4}$, proximal myopathy is not described in reported cases. These features may be explained by the low serum basal cortisol level but it warrants further explanation.

Headache and excessive sweating are common in pituitary GH secreting tumor. ${ }^{1,9,10}$ Our patient had both of these features. Headache may be due to the local effect of the tumor and excessive sweating may result from the effect of excessive growth hormone itself on the sweat glands.

Up to a certain limit 'heightism' is welcome in our society. But the height that is attained in gigantism is likely to be a cause of social embarrassments as is found in case series which indicates that there is a high incidence of severe depression, social withdrawal, and low self-esteem among giants. ${ }^{1}$ But in our patient no such complaint was noticed, rather he was a bit proud of being an unusual character in his society. He was anxious of being unable to earn his livelihood due to his weakness, not of his tallness.

Serum prolactin level of this patient was high. Serum testosterone, LH and FSH were in the low normal limit indicating hypogonadotrophic hypogonadism though clinically it was not evident. This condition may be due to tumor growth and /or compression that may impair gonadotrophin secretion. On the other hand hyperprolactinaemia or the prolactin like effect of excess GH may impair gonadotrophin and gonadal function. GH suppression of sex hormone binding globulin may also lead to low serum testosterone level. In this case plasma free testosterone level may be normal in maintaining the normal growth of phallus.

\section{Conclusion:}

Gigantism is an extremely rare disease. Thus far, about 100 cases are reported. So, clinical features are not readily available in resource papers as it is available in case of acromegaly. However, the diagnosis of this condition is straightforward with the cardinal feature of accelerated growth, radiological scanning, and hormonal assays. But still we need to know the varied manifestations with its pathophysiological explanation. This will help us to increase our insight and interest in this rare condition which will ultimately lead to a better understanding and management of it.

\section{References:}

1. Eugster EA, Pescovitz OH. Commentary: gigantism. Journal of Clinical Endocrinology and Metabolism 1999; 84 :4379-4384.

2. Sotos JF. Overgrowth, section II. Clin Pediatr 1996;35(11):579 -590.

3. Whitehead EM, Shalet SM, Davies D, Enoch BA, Price DA, Beardwell CG. Pituitary gigantism: a disabling condition. Clin Endocrinol 1982; 17:271-277.

4. Rix M, Laurberg P, Hoejberg AS, Jacobsen BB. Pegvisomant therapy in pituitary gigantism: successful treatment in a 12-year-old girl. European Journal of Endocrinology 2005;153:195-201

5. Blumberg DL, Sklar CA, David R, Rothenberg S \& Bell J. Acromegaly in an infant. Pediatrics 1989; 83: 998-1002.

6. Extabe J, Gaztambide S, Latorre P, Vasquez J. Acromegaly: an epidemiological study. J Endocrinol Invest 1993;16:181-187.

7. Fuqua JS, Berkovitz GD. Growth hormone excess in a child with neurofibromatosis type I and optic pathway tumor: A patient report. Clin Pediatr1998; $37: 749-752$.

8. Aron DC, Findling JW \& Tyrrell JB. Hypothalamus \& Pituitary Gland. In: Gardner DJ \& Shoback D (Edis.). Basic and Clinical Endocrinology. $8^{\text {th }}$ Edition. The McGraw-Hill Companies, Inc. NY. 101-153.

9. Ayuk J, Sheppard MC. Growth hormone and its disorders: Postgrad Med J 2006;82:24-30. 